\title{
Ungleiche Geschwister. Wien und die Städte Niederösterreichs
}

\begin{abstract}
Der Beitrag zeichnet die Entwicklung der Städte Niederösterreichs im I9. Jahrhundert nach. Entlang von typologischen Unterscheidungen und Fallbeispielen untersucht er die Verzahnung von Urbanisierung und Industrialisierung. Diese Prozesse bewirkten die Transformation städtischer Lebensräume und die Herausbildung neuer Hierarchien, sowohl in den Städten als auch zwischen ihnen. Die Dominanz der Metropole Wien verhinderte die Ausbildung einer mehrpoligen Städtelandschaft und führte längerfristig zu einer Vertiefung struktureller und regionaler Ungleichheiten. Im Schatten der Metropole bildeten sich in Kleinund Mittelstädten spezifische Formen der „Modernität“ und „Urbanität“, die einen wesentlichen Einfluss auf die infrastrukturelle Expansion und städtebauliche Assanierung hatten.
\end{abstract}

Unequal Siblings. Vienna and the Cities of Lower Austria. This chapter discusses the development of Lower Austrian cities in the $19^{\text {th }}$ century. Based on typological distinctions and case studies, it investigates the intertwinement of urbanization and industrialization. These processes brought about the transformation of urban living and the formation of new hierarchies within and between cities. The dominance of the metropolis of Vienna impeded the emergence of a multipolar urban landscape and led to the deepening of structural and regional inequalities in the long run. In the shadow of the metropolis, small and medium-sized towns established specific forms of "modernity" and "urbanity", which had a tangible influence on infrastructural expansion and urban redevelopment.

Keywords: urban history, urban hierarchies, modernization, urbanity, Lower Austria, small towns

doi.org/10.52035/noil.2021.19jh02.16

Veröffentlicht nach externer Begutachtung (doppelblind) / published after external peer review (double blind) 